\title{
Scapular winging in a patient with Arnold-Chiari malformation type 1 and syringomyelia
}

\author{
Vijay Chandran, Rohit Pai, Anirudda Deshpande
}

${ }^{1}$ Department of Neurology, Kasturba Medical College, Manipal University, Manipal, Karnataka, India

\section{Correspondence to}

Dr Vijay Chandran, vj_chandran@rediffmail.com

Accepted 9 March 2014

\section{DESCRIPTION}

A 30-year-old male presented with a 15-year history of proximal weakness and decreased temperature sensation in both upper limbs. There was no history to suggest a hereditary connective tissue disorder, and no prior trauma. On examination, he had lateral winging of the scapula (WOS) with the superior angle displaced laterally (figure 1), mild weakness of bilateral upper extremities, reduced pain and temperature sensation in dermatomes C2 to $\mathrm{T} 3$, and normal proprioception, while tendon reflexes were absent in the upper limbs and brisk in the lower limbs, and plantars were extensor. MRI of the spine revealed a large syrinx with an Arnold-Chiari malformation (ACM) type 1 (figure 2). X-rays of the craniovertebral junction did not reveal occipitoatlantoaxial hypermobility.

WOS is a condition where the medial border of the scapula is prominent due to weakness of the serratus anterior, trapezius or rhomboid muscles. ${ }^{1}$ Weakness of the serratus anterior leads to medial winging (the medial border lies more medially), whereas weakness of the trapezius or rhomboids leads to lateral winging (the medial border lies laterally). ${ }^{1}$ This shift is due to the unopposed action of normal muscles. In trapezius weakness, the scapula is rotated such that the superior angle is laterally displaced, whereas in rhomboid weakness, the inferior angle is laterally displaced. ${ }^{1}$ In our patient, ACM type 1 with syringomyelia led to trapezius weakness and lateral WOS, an association that has been infrequently reported. ${ }^{2} 3 \mathrm{He}$ underwent posterior fossa decompression with duroplasty, and on follow up 6 months later, his neurological examination remained unchanged.

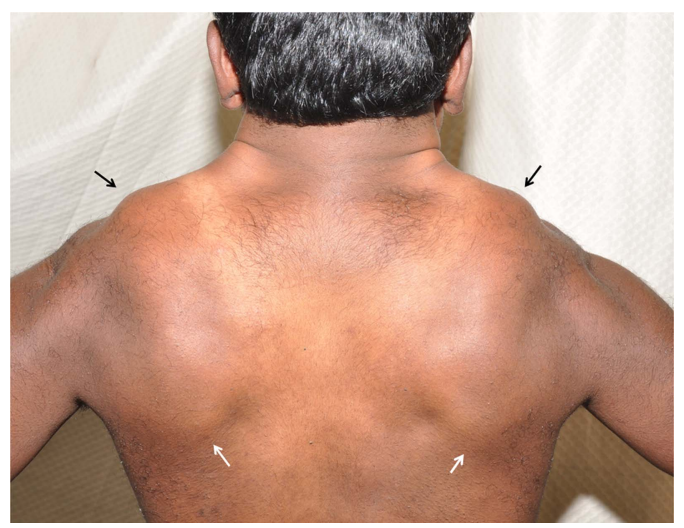

Figure 1 Photograph of the patient showing lateral winging of both scapulae with the superior angle (black arrows) displaced laterally as compared to the inferior angle (white arrows) suggestive of trapezius weakness.

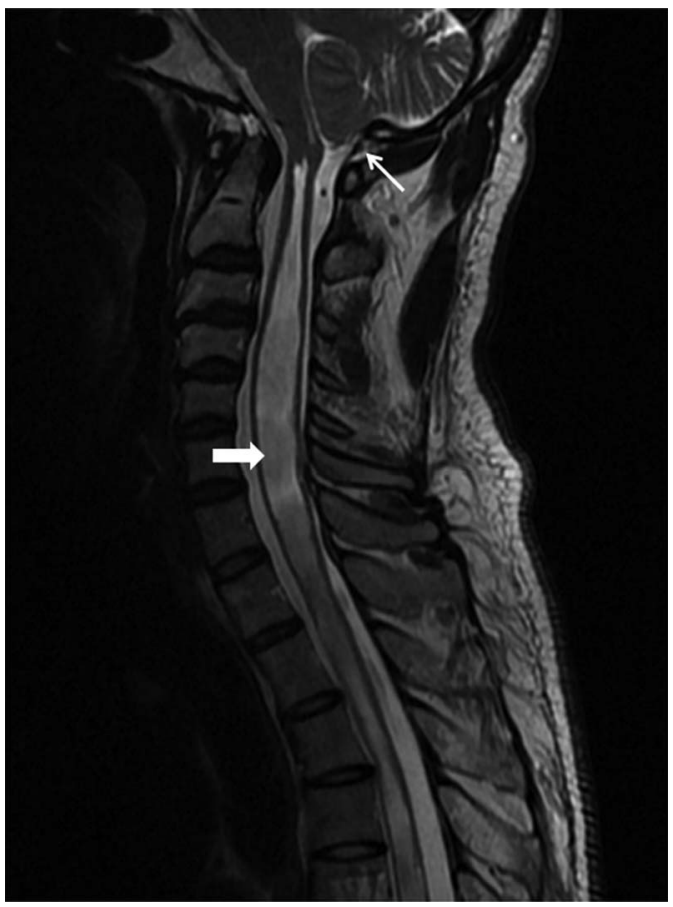

Figure 2 T2 weighted sagittal images showing mild tonsillar descent (thin arrow) below the foramen magnum suggestive of Arnold-Chiari malformation type 1. In addition, syringomyelia (thick arrow) extending from segment C1 into the thoracic spinal cord is seen.

\section{Learning points}

Scapular winging is due to weakness of the serratus anterior, trapezius or rhomboid muscles.

- Scapular winging is classified as medial or lateral based on the direction of displacement of the medial border of the scapula.

- Medial winging occurs due to weakness of the serratus anterior.

- In lateral winging, if the superior angle of the scapula is displaced laterally it suggests weakness of the trapezius muscle, if the inferior angle is displaced laterally it suggests weakness of the rhomboids.

Contributors All authors contributed to conception, acquisition of data and drafting of this article.

Competing interests None.

Patient consent Obtained.

Provenance and peer review Not commissioned; externally peer reviewed. 


\section{REFERENCES}

1 Martin RM, Fish DE. Scapular winging: anatomical review, diagnosis, and treatments. Curr Rev Musculoskelet Med 2008;1:1-11.

2 Tubbs RS, Oakes WJ. Winged scapula as the presenting symptom of Chiari I malformation and syringomyelia. Childs Nerv Syst 2007; 23:255-7.
3 Niedermaier N, Meinck HM, Hartmann M. Cervical syringomyelia at the C7-C8 level presenting with bilateral scapular winging. I Neurol Neurosurg Psychiatry 2000;68:394-5.

Copyright 2014 BMJ Publishing Group. All rights reserved. For permission to reuse any of this content visit http://group.bmj.com/group/rights-licensing/permissions.

BMJ Case Report Fellows may re-use this article for personal use and teaching without any further permission.

Become a Fellow of BMJ Case Reports today and you can:

- Submit as many cases as you like

- Enjoy fast sympathetic peer review and rapid publication of accepted articles

- Access all the published articles

- Re-use any of the published material for personal use and teaching without further permission

For information on Institutional Fellowships contact consortiasales@bmjgroup.com

Visit casereports.bmj.com for more articles like this and to become a Fellow 